Final article:

Lindgreen, A., Palmer, R., and Trienekens, J. (2005), "Relationships within the supply chain: a case study”, Journal on Chain and Network Science, Vol. 5, No. 2, pp. 85-99. (ISSN 1569-1829)

For full article, please contact LindgreenA@cardiff.ac.uk

\title{
Relationships within the Supply Chain: A Case Study
}

\author{
Adam Lindgreen ${ }^{1,2}$ \\ Eindhoven University of Technology \& Harper Adams University College
}

Roger Palmer ${ }^{3}$

Cranfield School of Management

Jacques Trienekens ${ }^{4}$

Wageningen University

Keywords: marketing practice; case study; Dutch pork supply chain; trust.

\footnotetext{
${ }^{1}$ Corresponding author. The authors contributed equally. They thank Karst Vellinga for assistance in data collection. Also many thanks to the pork chain businesses that participated in the research.

2 Adam Lindgreen, Department of Organisation Science and Marketing, Faculty of Technology Management, Paviljoen R 00.07, Eindhoven University of Technology, Den Dolech 2, P.O. Box 513, 5600 MB Eindhoven, the Netherlands. E-mail: a.lindgreen@tm.tue.nl. Telephone: + 31 - (0) 40247 3700. Fax: + 31 - (0) 402468054

${ }^{3}$ Roger Palmer, Cranfield School of Management, Cranfield University, Cranfield, Bedford, MK43 0AL, UK. Email: r.a.palmer@cranfield.ac.uk. Telephone: + 44 (0) 1234751 122. Fax: + 44 - (0) 1234751806.

${ }^{4}$ Jacques Trienekens, Management Studies Group, Building 201, Wageningen University, Hollandseweg 1 , 6706 KN Wageningen, the Netherlands. E-mail: jacques.trienekens@wur.nl. Telephone: + 31 (0) 317482558 . Fax: + 31 (0) 317485454 .
} 


\begin{abstract}
In an effort to clarify and reconcile different perspectives of transactional and relational marketing practices the 'Contemporary Marketing Practice' (CMP) group developed a classification scheme of marketing practices. Research by the CMP group identifies that in any particular context there are multiple exchange paradigms present. That is, different combinations of marketing practices are possible. The food supply chain is characterized by highly interdependent partnerships and a span of relationship types (Hogarth-Scott, 1999). The aim of this study is to compare and contrast transactional and relational marketing practices within the Dutch pork supply chain and to consider the contextual factors influencing such practices. The year of reference for this study is 2003-2004. Using a case study approach we identify that all chain players practice transactional and relational marketing practices concurrently. Previous studies have indicated that the Dutch pork supply chain can be characterized by general mistrust, but our study indicates that the lack of trust is primarily towards slaughterhouses and retailers. In line with the literature on business relationships this can be explained by power imbalance and information asymmetry in the supply chain.
\end{abstract}




\section{Introduction}

The way in which marketing is being practiced is changing, which in turn is caused by dramatic changes in the business context. For example, in recent years, producers of consumer goods and services found that competition has become more pronounced not only in their own markets, but also in their customers' markets. Some channel customers and end-consumers sought not just simple transactions, but wanted relationships, networks, and interactions (Garbarino and Johnson, 1999; Levy and Weitz, 1998). Marketers therefore formulate activities to, and build interactions, relationships, and networks with a number of different, but often equally important markets. This contrasts with businesses that continue to base their model on transactions (e.g. Jackson, 1985). Overall, businesses which compete on the basis of relationships, networks, and interactions, increasingly focus on attracting, as well as developing and retaining customers.

The food supply chain, and in particular that of the meat sector, provides an interesting focus for study. The delicate nature of live animals, perishability of the processed product, interdependencies between chain members, and the increasing consumer awareness of environmental, food safety and animal welfare issues led Hogarth-Scott (1999) to describe the food industry as being characterized by "highly interdependent partnerships" in which channels become "dynamic webs". Hogarth-Scott describes relationships within chains as being "a wide band of hybrid relationships". To our knowledge, one challenge to the understanding and development of marketing practice has been the lack of empirical investigations aiming at describing marketing practices within networks, rather than between dyads. Also, few studies have examined how an organization's marketing practice relates to perceived customer need structures and their preferences, a gap identified by Coviello et al. (2002). The aim of this study, 
therefore, is to compare and contrast transactional and relational marketing practice within a supply chain and to consider the contextual factors influencing such practices.

\section{Literature Review}

\section{Multiple Exchange Paradigms}

Relationship marketing has now been recognized for more than two decades. However, since views of marketing are dependent on both the ontological and epistemological assumptions of the particular research tradition and the issues that each research tradition has chosen as its focus (Möller and Halinen-Kaila, 2000) it is not surprising that what constitute good marketing practices still means different things to different authors (Price and Arnould, 1998).

In an effort to clarify and reconcile these various views the 'Contemporary Marketing Practice' (CMP) group developed a classification scheme that builds upon content analysis of how European and North American research traditions have defined marketing in the literature (e.g. Brookes and Palmer, 2004). The scheme is based upon two themes of transaction marketing and relationship marketing characterized using five dimensions of marketing exchange and four managerial dimensions. As evident from Table 1, relationship marketing encompasses four distinct types of marketing: database marketing, e-marketing, interaction marketing, and network marketing, which together with transaction marketing constitutes the CMP classification of marketing practices (Coviello, Milley, and Marcolin 2001; Coviello et al., 2002). It should be appreciated that the scheme does not place distinct boundaries between the different marketing types, and that the marketing types are not necessarily independent and mutually exclusive. 


\section{\{Insert Table 1 About Here}

Transaction marketing involves a company attracting and satisfying potential customers by managing the elements of the marketing mix, whereby the company actively manages communication to customers in a mass-market in order to create discrete, or one-off, transactions. The overall approach is to use aggressive marketing to attract customers. Marketing activities are intended to continuously search for new customers to get sales. The strategy is focused on the products and prices. Customer contact is arms-length and impersonal, with no individualized communication or personal contact. Relationships with customers are characterized as discrete, transactions. The company focuses its marketing resources on the product, service, price, distribution, and promotion capabilities. Marketing activities are mainly carried out by functional marketers, including sales managers and product-development managers. Communication with customers is undifferentiated. Meetings with customers are mainly at a formal, business level.

Database marketing involves using a database technology to create a type of relationship that allows companies to compete in a manner different from transaction marketing. The intent is to retain identified customers in a specific market segment although marketing is still to the customer, rather than with the customer. Relationships as such are not close or interpersonal, but are facilitated and personalized through the use of database technology. The strategy is focused on customers in addition to the product/brand. The purpose is to acquire customer information for the company's database in addition to meeting financial objectives, including increasing profits. Contact with customers is somewhat personalized via technology. The relationship with 
customers is characterized as occasional contact, for example by e-mail. Resources are invested in database technology to improve customer management. Marketing activities are mainly carried out by specialist marketers, including customer service managers and loyalty managers. Meetings with customers are mainly at a formal level, yet attuned to the situation of the individual customer.

E-marketing is characterized as using the internet and other interactive technologies to create and mediate two-way dialogue between the company and many identified customers. The dialogue is ongoing and happens in real time. Also, the purpose is to create information-generating dialogue with many identified customers. Resources are invested in operational assets, for example information technology, website, and marketing, and functional systems integration, for example electronic marketing. Marketing activities are increasingly carried out by cross-functional marketing teams. Meetings with customers are mainly at a formal level, yet customized using interactive technologies.

Interaction marketing practice implies face-to-face interaction between the company's employees and individual customers. As such, it is truly with the customer, as both parties invest resources to develop a mutually beneficial, interpersonal, and cooperative relationship. The relationship is ongoing and often long term. Substantial marketing resources are invested in establishing, maintaining, and developing relationships. Marketing activities are mainly carried out by employee teams spanning the company's different functions and levels. Communication with customers also involves employees within the selling company personally interacting with individuals within the buying company. Meetings with customers are both at a formal business level, and at an informal social level on a one-to-one basis. 
Network marketing occurs across companies, with resources being committed to developing the company's position in a network of company-level relationships. Marketing activities are intended to coordinate activities between the company, customers, and other parties, for example suppliers and service providers, in a wider marketing system. The contact with customers is from impersonal to interpersonal, and is characterized as ongoing. Marketing activities are carried out by marketers and cross-functional teams, but also the managing director is involved. Marketing communication involves senior managers networking with managers from a variety of organizations in the market(s) or the company's wider marketing network. Meetings with customers are at both a formal business level, and at an informal social level in a wider organizational network.

There is evidence that not necessarily all suppliers and buyers of industrial goods, consumer goods, industrial services, or consumer services want close relationships. That is, in any particular context there are multiple exchange paradigms present (Brodie et al., 1997). A conceptual model was later developed by Pels, Coviello, and Brodie (2000), which allows diversity to be represented in marketing exchange by stressing that the exchange paradigm of both the buyer and the seller is key, and that the choice between a transactional or relational exchange depends on the environment and the interpretation of it made by the actors involved. Later research validated (Lindgreen and Pels, 2002) and also extended the model to include market growth and density (Beverland and Lindgreen, 2004), demonstrating some of the contingent factors influencing relationships (Selnes, 1998). In their agrifood chain study Hobbs and Young (2000) identified a number of contingent factors relevant to the subject of this study, 
the Dutch pork supply chain, including factors such as perishability, visible and invisible quality factors, and regulatory and technological drivers.

\section{Changes in Food Supply Chains}

Traditionally having embraced short-term transactions (Barkema, 1992; Barry, Sonka, and Lajili, 1992; Kalfass, 1993; Sporleder, 1992), agribusiness and the food industry changed their marketing practice, as they became part of horizontal and vertical relationships, networks, and interactions (Behner and Bitsch, 1995; Hughes, 1994; Srivastava, Ziggers, and Schrader, 1998). The result is that relational marketing strategies are increasingly widespread (Bourlakis, 2001; Hughes, 1994; Seth and Randall, 2001). For example, using the information from loyalty cards, food retailers are now seeking to offer products that particularly appeal to end-consumers, and different shopping options are becoming available such as 24/7 opening hours, home shopping, and home delivery (Hogarth-Scott, 1999). Another example is the British food retailing sector that has challenged the traditional structure of the meat supply chain and set up close relationships with their suppliers to be able to offer end-consumers meat guaranteed to be free of mad cow disease (Lindgreen, 2003; Lindgreen and Hingley, 2003). Meat from these suppliers is therefore 'farmed-assured' (Ratzan, 1998). In summary, the way in which food companies practice marketing relates to the extent to which they are transactional or relational in their orientation.

\section{The Dutch Pork Supply Chain}


The Dutch pork supply chain was chosen for study, as it has changed dramatically over the past years. ${ }^{5}$ The Dutch pork sector is the fourth biggest exporter of pork meat in the world (ABN AMRO, 2002). Important factors driving change in the sector have been high costs of production and governmental regulations (Backus and Dijkhuizen, 2002); issues of food safety and animal welfare, environmental protection, and traceability (Sharp and Reilly, 1994; Verbeke, 2001; Verdonk, 2001; Wandel, 1994); and consumer preferences, including nutritional value, sensorial aspects, and ease of preparation (Saxowsky and Duncan, 1998; Verbeke, 2001; Ziggers, 1998). The supply chain has undergone structural and organizational change. Competition has increased, as the market is oversupplied, and former cost advantages have disappeared (Maijers et al., 1999).

To compete successfully it is argued that increased chain cooperation is a strategic imperative (Backus and van der Schans, 2000; den Ouden et al., 1996; Perry, 1989). In this regard the Dutch quality system 'Integrated Quality Control' (in Dutch: Integral Keten Beheersing, IKB) can be considered an instrument for providing the necessary vertical liaisons among the players in the chain (Srivastava, 1999). Introduced in 1992 by the Product Board for Livestock, Meat, and Eggs (PVE) in cooperation with the livestock and meat sector, the IKB system sets out standards for feed quality, hygiene, transport, information, and use of veterinary products, among other things (Kanis, Groen, and de Greef, 2001; PVE, 2003). The system covers about 80 percent of all pigs slaughtered in the Netherlands, and most Dutch retailers and butchers sell pork-meat products produced according to the IKB system (Kanis, Groen, and de Greef, 2001).

\footnotetext{
${ }^{5}$ The case description in this article is based on the 2003 situation in the Dutch pork sector. Since 2003, further concentration has emerged in this sector. For example, the two largest meat processors/slaughterhouses in the Netherlands merged in 2005.
} 
However, the implementation of a more relational approach to marketing practice has not been without problems. The lack of trust, defined as "a willingness to rely on an exchange partner in whom one has confidence" (Moorman, Deshpandé, and Zaltman, 1993: p. 3), between the chain players has frequently been mentioned (Bondt et al., 2003; Srivastava, 1999; Urlings, Walstra, and Tacken, 2000). An imbalance of power in relationships and information asymmetry in the chain is evident.

With the IKB system covering some 80 percent of all pork-meat products our research focused on the volume-driven part of the supply system (omitting organic pork meats and other niche products). The slaughterhouses can be considered as chain leaders (Visser, Vlaar, and Neves, 2000), and it was therefore believed to be appropriate to 'network' from the slaughterhouse to the other supply chain players, both upstream and downstream. Capturing the understanding of both sides of the dyads in the pork supply chain is important when examining interaction as a major source of channel conflict is goal- and domain-dissensus (Achrol and Etzel, 2003). We obtained data from the supply chain of the case study slaughterhouse, one of the biggest slaughterhouses in the Netherlands. The characteristics of the Dutch pork supply chain and case study respondents are summarized in Table 2 to provide a rich description of the background to the case. Please note that for reasons of confidentiality the true identity of the respondents has been left out.

\{Insert Table 2 About Here $\}$ 
This study therefore seeks to examine in more depth how members of this particular food supply chain practice marketing. Secondly, the understanding of how, if at all, they seek to implement relationship marketing and the factors that are contingent upon such practice (Kanis, Groen, and de Greef, 2001; Ziggers, 1998).

\section{Methodology}

Since we were seeking to understand the complexity of marketing practices an embedded case study methodology was employed (Yin, 1994). Our chosen research design is consistent with

previous findings that show that successful implementation and management of relationship marketing is a complex, dynamic process. This places the use of relationship marketing within a complex environmental context (Achrol and Etzel, 2003; Joshi and Campbell, 2003; Pettigrew, Woodman and Cameron, 2001). Anderson (1995) sees the need for case studies of relationships in business markets and the development and evolution of supplier-customer relationships, recommending the use of multiple case studies that are embedded within a wider historical context. The case study methodology allows the examination of such complexities.

The majority of the case study data comes from face-to-face interviews guided by a protocol divided into three parts. One respondent each at the feed producer, dealer, trader, slaughterhouse/ processor and retailer levels, together with three producers were interviewed (see Table 2). The case work was conducted during 2003-2004. 
The interview protocol was adjusted for producers, as these are mainly family-owned businesses. The first two parts of the protocol concern marketing practices and are organized around the following topics (Coviello et al., 2002):

- the participant's organization (size, sector, etc.).

- the organization's customers.

- marketing practices with major customers.

- marketing practices with customers other than major customers.

- performance.

- use of technology in the organization.

- value creation and delivery in the organization.

- the participant's view on marketing.

- the participant.

The third part of the protocol is concerned with trust. Three open-ended questions deal with:

- lack of information (e.g., Morgan and Hunt, 1994)

- abuse of economic power (e.g., Bozzo, 2000)

- trust in the Dutch pork supply chain.

The data concerning contemporary marketing practices is derived by measuring the different types of marketing using 5-point Likert scales. The practices are made explicit by summing the scores across the relevant nine items and then dividing by 45 to develop an index ranging from 0 to 1.0. The following index levels are used: low $=$ index less than 0.5 , medium $=$ index between 0.5 and 0.75 , and high $=$ index greater than 0.75 (Coviello et al., 2002). 
Analysis of the verbatim transcripts occurred soon after the first few interviews, allowing interpretations to inform and direct subsequent interviews (Glaser and Strauss, 1967). The analysis of interview data was carried out using Eisenhardt's (1989) two-stage method of withincase and cross-case analysis. Within-case analysis involved writing up a summary of each individual case in order to identify important case level phenomena (Eisenhardt, 1989). The open-ended questions (part one and two of the interview protocol) were analyzed according to the guidelines of Miles and Huberman (1994). The volume of data was condensed through coding and memoing, as well as reducing the data by eliciting themes, clusters, and patterns. The themes and coding scheme, noted below, were obtained by comparison and iteration between the literature review and the interviews:

- Changes in the pork supply chain: consumer demands, technology, competition, environmental rules, and specialization.

- Changes in marketing practice: use of technology, customer loyalty, relationship development, and brand management.

- Trust in the pork supply chain: trust, interdependence, power, and information.

In all situations, case studies and interpretive reports were returned to participants for comment, a step that helped enhanced the validity of the method (Perry, 1998).

\section{Findings}

In this section, findings are presented according to changes in the pork supply chain (Table 3a), changes in marketing practice (Table 3b), and trust in the pork supply chain (Table 3c). 
\{Insert Tables 3a, 3b, and 3c About Here $\}$

\section{Changes in the Pork Supply Chain}

The changes in the pork supply chain that are mentioned include changing consumer demands, IT, and competition. Regarding changing consumer demands; food safety and animal welfare were primarily mentioned. The issue of food safety was raised by all chain players and is predominantly seen as an important construct related to the new quality systems implemented throughout the chain. Animal welfare is mentioned by the pork producers, the pork-trader, and the slaughterhouse who are also the chain players dealing directly with live pigs. IT is mentioned by most of the chain players. Regarding intensified competition, five players raised this issue. The competition is primarily based on the struggle for supply from the decreasing number of pork producers, itself influenced by low production costs in other countries. The only chain member who did not discuss competition was the retailer.

\section{Changes in Marketing Practice}

The changes in marketing practice that are primarily mentioned are; customer retention, relationship development, and IT. Almost all chain members mentioned the importance of customer retention and relationship development. Only the retailer, the last member of the chain, did not. Regarding IT, only slaughterhouse and retailer, the downstream members, mentioned development of IT for marketing purposes. The slaughterhouse considers IT as an important tool 
to create and retain long-term relationships with customers. The slaughterhouse is currently implementing a sophisticated IT-based chain quality system.

\section{Trust in the Pork Supply Chain}

Regarding trust in the chain, the feed company, dealer, and the pork producers (upstream in the pork chain) reported a lack of information exchange. The feed company and the pork producers discussed a lack of information from the slaughterhouses. The dealer and the pork producers saw a lack of information from the retailers. The slaughterhouse and the pork-traders commented that information could be better, but feel no great lack of specific information. The retailer mentioned no problems regarding information exchange. All chain members perceived a power imbalance in the chain. The feed company, dealer, pork producers, and the pork trader believed that the main point of power lies with the slaughterhouses and the retailers. Slaughterhouse and retailer considered the main point of power is at the slaughterhouses. There is a widespread feeling in the chain that those members who have most power abuse it.

The pork producers and pork trader feel retailers abuse their power by price making, creating an unequal share of chain profits. The pork producers also blame slaughterhouses for this power abuse. According to chain members the slaughterhouses are abusing their power by importing cheap pigs, a tactic for price management. Furthermore, feed company and the pork producers complain about the demand for sophisticated quality systems by the down-stream chain members, without recompense through better prices. 
All chain members mentioned a lack of trust towards a particular chain player, with the exception of the dealer. This lack of trust is directed towards the downstream chain members: retailers and slaughterhouses. Furthermore, the chain players who mentioned an abuse of power by slaughterhouses and/or retailers also mentioned a lack of trust with respect to these chain members. A lack of trust due to a lack of information is only brought up by the feed company and the pork producers. In both cases this lack of trust is towards the slaughterhouses.

\{Insert Table 4 About Here $\}$

Table 4 shows the indexes by marketing type of the supply chain members. In the chain the highest scores are recorded for interaction marketing. Only the retailer does not show high levels of interaction marketing. In this regard the retailer in the case study practices a transactional/relational hybrid form of marketing (Coviello et al., 2002), whereas the other players practice a predominantly relational form. This is in line with earlier studies (see, for example, Brookes and Palmer, 2004). High levels of network marketing were found for the feed company and the slaughterhouse.

\section{Discussion and Conclusions}

First, the study demonstrated that the players of the Dutch IKB pork supply chain practice transaction marketing and different forms of relationships marketing concurrently. These findings are similar with outcomes of previous CMP studies (Brookes and Palmer, 2004). It should be noted that there is no quantitative data concerning the contemporary marketing practice of pork 
producers due to difficulties in gathering data. However, the qualitative data indicates that pork producers practice various types of relationships marketing and that they have very strong longterm relationships with their major customers, the pork traders. The drivers of change in marketing practice relate to the consolidation of the industry and the increasing requirements for food security, animal welfare and environmental considerations and, in this respect, retailers have both power and influence in driving such changes.

The view of Fearne, Hornibrook, and Dedman (2001) that retailers have an important role in signaling consumer interests to the supply chain is substantiated. The results demonstrate a relatively high degree of integration, whereby members are mutually dependant with mechanisms in place to balance supply and demand. This matches the batch production nature of the relatively small pig producers with the demand for consistent supplies of raw material needed by the slaughterhouses which are capital intensive and operate on a continuous basis. When supply and demand fail to match within the supply chain and the price becomes unacceptably high to the slaughterhouse then imports will be brought in to make up the deficit. In addition, the increasing requirements for food quality assurance provide an incentive for producers to maintain standards and for slaughterhouses to source from established suppliers. The continuing integration within the industry reduces the choice set of suppliers and further encourages dependency, supported by the delicate and perishable nature of the product.

However the principles of relationship marketing emphasize the mutual nature of benefits (Grönroos, 1990), and this may be one of the additional benefits of adapting practice. Many authors propose that trust is an important enabler of integration within supply chains, but the results of this study demonstrate variable and sometimes low levels of trust. Dapiran and 
Hogarth-Scott (2003), in their study of food retailing in the UK and Australia, argue that cooperation and trust are not the same, noting that industry and retailer concentration are a factor in this. In a previous study Hogarth-Scott (1999) proposed that power is the functional equivalent of trust, producing the same outcome, and that cooperation is the result. Although changes in practice can be distinguished the result so far has been to increase cooperation, following the signals provided by retailers and government, but not necessarily trust. Selnes (1998) notes the "relatively low importance of trust in maintaining relationships", and a consequence of changes in supply chain practice may be increased cooperation, but not necessarily trust.

Hogarth-Scott (1999) notes the importance of context in influencing relationships. Relative power within relationships is affected by the supply and demand balance of pigs, produced in homogenous batches, against the processors need for a continual supply of raw material in order to achieve high capacity utilization. The use of power is therefore more constrained within business-to-business, dependant relationships by the acceptable limits of price variations. However, retailers and slaughterhouses, with their market knowledge and aggregated buying power, are more overt in their use of power and hence transactional in terms of their marketing practice.

A number of studies show that the Dutch pork supply chain can be characterized by a lack of trust between adjacent members (Boston, Ondersteijn and Giesen, 2004). Most of these studies describe a lack of trust between pork producers, slaughterhouses, and retailers, and competition is primarily based on price (Bondt et al., 2003; Urlings et al., 1999; Ziggers, 1998). Our study again demonstrates the importance of price, and indicates moderate levels of trust. From the members of this chain it can be concluded that there is a power imbalance. The results show that this power 
imbalance is the major reason for the lack of trust towards the slaughterhouses and the retailer. The perceived abuse of power accentuates the level of distrust. The same development is described in extant literature, which indicates that an asymmetry of power can create tension among chain players and have a negative impact on trust (e.g., Bozzo, 2000; Bunte et al., 2003).

Bondt et al. (2003) contend that a lack of information from slaughterhouses to pork producers causes a lack of trust in the pork chain. From the literature it can be concluded that there is a positive relationship between communication (information sharing) and trust (e.g., Mohr and Spekman, 1994; Morgan and Hunt, 1994). Our study indicates that information sharing in the pork supply chain is not optimal, especially the information flow from slaughterhouses and retailer towards upstream members. The lack of information from slaughterhouses and retailers concerning prices in particular causes a great lack of trust in this chain. This is accentuated by the role of the trader, acting as a market broker by balancing supply and demand, to whom opacity of information is an advantage and this acts as constraint to cooperation and information sharing particularly with respect to price (Boston, Ondersteijn, and Giesen, 2004).

Research shows that trust is seen as the most important foundation for relationship marketing (Andaleeb, 1996; Crosby, Evans and Cowles, 1990; Morgan and Hunt, 1994). Yet the results of this study show that all members of the chain are practicing medium to high levels of relationship marketing and trust remains at low levels. The contextual factors that impinge of this include the asymmetry of power, poor communication, low levels of trust - distinct from cooperation, and price fluctuation associated with supply and demand variation and in turn lack of information. 
A study of the Danish pork supply chain assists in the understanding of these contextual factors (Hobbs, Kerr, and Klein, 1998). The Danish pig industry is internationally competitive, yet suffers many of the constraints of other European producers - relatively high costs, environmental constraints, retailer concentration etc. The Dutch pig industry is characterized by corporate organizations at each stage of the supply chain (Boston, Ondersteijn, and Giesen, 2004), whilst the Danes have an umbrella organization, Danske Slagterier, which coordinates and encourages supply chain cooperation and undertakes activities such as training, market research and technology development on behalf of the supply chain. In addition there is substantial cross ownership at different levels of the supply chain and hence incentive for greater mutuality of interests. The Danish industry, in contrast to the Dutch supply chain discussed here, shows not just cooperation but high levels of trust with mechanisms for agreeing prices and sharing information, long term contractual commitments which in turn reduce transaction costs. In the longer term economies of scale are developed by industry wide initiatives resulting, for example, in complete traceability for food safety purposes giving a competitive advantage in export markets.

A contribution of this study is its quantitative examination of aspects of marketing that provides insight into the extent to which firms perform different marketing practices. Furthermore, whereas literature tends to examine single firms or bilateral relationships between firms this study encompasses an entire supply chain. To our knowledge this is the first to study examine marketing practices in such way. This study identifies that whilst marketing practices change and adapt in response to signals transmitted through the supply chain, the adoption of relational practices does not necessarily result in high levels of trust but can improve cooperation. To achieve higher levels of trust greater congruence of objectives by information sharing, long term 
agreements particularly with respect to pricing mechanisms and quality criteria result in the mutual benefit postulated by relationship marketing exponents. This is achieved by reducing transaction costs, responding to market needs and capturing volume as a result, and longer term economies of scale by improvements in production techniques.

Fruitful areas for further research include the relationships between transactional and relational marketing practices on the one side and power, trust, and information exchange on the other using larger data sets and different supply chains. The findings of this extensive case study support the design of such research.

There are several limitations to the study. First, no quantitative data was obtained from pork producers. Future research should include marketing type data collection at producer level. Second, only one trader was included in the study although it is known from the literature that there are different kinds of traders some of which deliver exclusively to the slaughterhouse in the case (socalled exclusive middlemen) or to other slaughterhouses. Also, some traders focus on relationships and added value, while others emphasize the open market and bulk production (Burgers, 2003). In order to replicate and contrast our findings any future research should include a more diverse set of members of the supply chain, or as is indicated here the network of relationships.

\section{References}

ABN AMRO (2002), Varkenshouderij bedrijfstakonderzoek. 
Achrol, R. S. and Etzel, M. J. (2003), "The structure of reseller goals and performance in marketing channels", Journal of the Academy of Marketing Science, Vol. 31, No. 2, pp. 146163.

Andaleeb, S. S. (1996), "An experimental investigation of satisfaction and commitment in marketing channels: the role of trust and dependence", Journal of Retailing, Vol. 72, No. 1, pp. 77-93.

Anderson, J. C. (1995), "Relationships in business markets: exchange episodes, value creation, and their empirical assessment", Journal of Academy of Marketing Science, Vol. 23, No. 4, pp. 346-350.

Anonymous (1999) "Kwaliteit in de keten," De Molenaar, 27 August, pp.10-14.

Backus, G. B. C. and Dijkhuizen, A. A. (2002), "The future of the European pork chain", in the Allen D. Leman Swine Conference Proceedings, pp. 8-17.

Backus, G. B. C. and van der Schans, J. W. (2000), Pig Farmers in Dialogue with Society. Den Haag: LEI.

Barkema, A. (1992), "Reaching consumers in the twenty-first century: the short way around the barn", American Journal of Agricultural Economics, Vol. 75, No. 5, pp. 1126-1131.

Barry, P. J., Sonka, S. T., and Lajili, K. (1992), "Vertical coordination, financial structure, and the changing theory of the firm", American Journal of Agricultural Economics, Vol. 74, No. 5, pp. 1219-1225.

Behner, M. and Bitsch, V. (1995), "Abnehmer-Lieferanten-Beziehungen im Produktionsgartenbau. Eine transaktionskostentheoretische Analyse", Agrarwitschaft, Vol. 44, No. 3, pp. 131-137.

Beverland, M. and Lindgreen, A. (2004), "Relationship use and market dynamism: a model of relationship evolution", Journal of Marketing Management, Vol. 20, No. 7/8, pp. 825-858. 
Bondt, N., van der Kroon, S. M. A., Puister-Jansen, L. F., Bogaardt, M. J., and Folbert, J. P. (2003), Prikkels voor naleving van voedselveiligheidseisen door varkenshouders binnen en buiten ketengarantie systemen. Den Haag: LEI.

Boston, C., Ondersteijn, C., and Giesen, G. (2004), "Using stakeholder views to develop strategies for the Dutch pork supply chain", Proceedings of the 14th Annual IAMA Conference, June 12-15, Montreux, Switzerland.

Bourlakis, M. A. (2001), "Future issues in European supply chain management", in Eastham, J. F., Sharples, L., and Ball, S. D. (2001), Food Supply Chain Management. Oxford: Butterworth-Heinemann, pp. 297-303.

Bozzo, C. C. (2000), Regular and Stable Industrial Buying Behaviour: Are the Customers really Loyal? Published PhD thesis. CEROG-IAE d'Aix-en-Provence, Université Aix Marseille III, Clos Guiot, Puyricard.

Brodie, R. J., Coviello, N., Brookes, R., and Little, V. (1997), "Towards a paradigm shift in marketing? An examination of current marketing practices", Journal of Marketing Management, Vol. 13, No. 5, pp. 383-406.

Brookes, R. and Palmer, R. (2004), The New Global Marketing Reality. Basingstoke: Palgrave Macmillan.

Bunte, F. H. J., Kuiper, W. E., van Galen, M. A., and Goddijn, S. T. (2003), Macht en prijsvorming in de agrofoodketens. Den Haag: LEI.

Burgers, J. (2003), Informatie: Doorgeschakeld in de keten. Unpublished MSc thesis. Ede: Department of Management, Wageningen University.

Coviello, N. E., Brodie, R. J., Danaher, P. J., and Johnston, W. J. (2002), "How firms relate to their markets: an empirical examination of contemporary marketing practices", Journal of Marketing, Vol. 6, No. 3, pp. 33-46. 
Coviello, N.E., Milley, R. and Marcolin, B. (2001), “Understanding IT-enabled interactivity in contemporary marketing”, Journal of Interactive Marketing, Vol. 15(4), pp. 18-33.

Crosby, L. A., Evans K. R. and Cowles, D. (1990) "Relationship Quality in Services Selling: An Interpersonal Influence Perspective," Journal of Marketing, Vol. 54, No. 3, pp. 68-81.

den Ouden, M., Dijkhuizen, A. A., Huirne, R. B. M., and Zuurbier, P. J. P. (1996), "Vertical cooperation in agricultural producing marketing chains, with special reference to product differentiation in pork", Agribusiness, Vol. 12, No. 3, pp. 277-290.

Eisenhardt, K. M. (1989), "Building theories from case study research", Academy of Management Review, Vol. 14, No. 4, pp. 532-550.

Fearne, A., Hornibrook, S., and Dedman, S. (2001), "The management of perceived risk in the food supply chain: a comparative study of retailer-led beef quality assurance schemes in Germany and Italy", International Food and Agri-business Management Review, Vol. 4, pp $19-36$.

Garbarino, E. and Johnson, M. S. (1999), "The different roles of satisfaction, trust and commitment in customer relationships", Journal of Marketing, Vol. 63, No. 2, pp. 70-87.

Glaser, B. G. and Strauss, A. L. (1967), The Discovery of Grounded Theory. New York, Aldine de Gruyter.

Hendrix UTD, (2003), Organisatie, www.hendrixutd.nl.

Hobbs, J. E., Kerr, W. A., and Klein, K.K. (1998), "Creating international competitiveness through supply chain management: Danish pork", Supply Chain Management, Vol. 3, No. 2, pp. 68-78.

Hobbs, J. E., Young, L. M. (2000), "Closer vertical coordination in agri-food supply chains: a conceptual framework and some preliminary evidence", Supply Chain Management; An International Journal, Vol. 5, No. 3, pp. 131-142. 
Hogarth-Scott, S. (1999), "Retailer-supplier partnerships: hostages to fortune or the way forward for the millennium?" British Food Journal, Vol. 101, No. 9, pp. 668-682.

Hughes, D. (1994), Breaking with Tradition. Wye: Wye College Press.

Jackson, B. B. (1985), Winning and Keeping Industrial Customers. Lexington, Massachusetts: Lexington Books.

Joshi, A. W. and Campbell, A. J. (2003), "Effect of environmental dynamism on relational governance in manufacturer-supplier relationships: a contingency framework and an empirical test", Journal of Academy of Marketing Science, Vol. 31, No. 2, pp. 176-188.

Kalfass, H. H. (1993), "Kostenvorteile durch vertikale Integration im Agrarsektor?" Agrarwirtschaft, Vol. 42, No. 6, pp. 228-237.

Kanis, E., Groen, A. F., and de Greef, K. H. (2001), Societal Concerns about Pork and Pork Production and their Relationships to the Production System. Ede: Animal Breeding and Genetics Group, Wageningen University.

Laurus, (2003), Companies Profile, www.laurus.nl.

Levy, M. and Weitz, B. (1998), Retailing Management. New York: Irwin/McGraw-Hill.

Lindgreen, A. (2003), "Trust as a valuable strategic variable in relationship marketing: different types of trust and their implementation", British Food Journal, Vol. 105, No. 6, pp. 310-328.

Lindgreen, A. and Hingley, M. (2003), "The impact of food safety and animal welfare policies on supply chain management: the case of the Tesco meat supply chain", British Food Journal, Vol. 105, No. 6, pp. 328-349.

Lindgreen, A. and Pels, J. (2002), "Buyer-seller exchange situations: four empirical cases", Journal of Relationship Marketing, Vol. 1, No. 3/4, pp. 60-93.

LNV (2003), Dossier klassieke vogelpest: Algemene informatie, www.minlnv.nl. 
Maijers, W., Vernooij, M., Folkerts, H., and Peters, M. G. M. (1999), Alberta \& the Western Hog Exchange: A Case Description on Vertical Co-ordination in Dutch Pork Industry, Rosmalen: AKK.

Miles, M. B. and Huberman, A. M. (1994), Qualitative Data Analysis, 2nd ed.. Thousand Oaks, California: Sage Publications.

Mohr, J. and Spekman, R. E. (1994), "Characteristics of partnership success: partnership attributes, communication behavior, and conflict resolution techniques", Strategic Management Journal, Vol. 15, No. 2, pp. 135-152.

Möller, K. K. and Halinen-Kaila, A. (2000), "Relationship marketing theory: its roots and direction", Journal of Marketing Management, Vol. 16, No. 1/3 pp. 29-54.

Moorman, C., Deshpandé, R., and Zaltman, G. (1993), "Relationships between providers and users of market research: the role of personal trust", working paper series. Cambridge, Massachusetts: Marketing Science Institute.

Morgan, R. M. and Hunt, S. D. (1994), "The commitment-trust theory of relationship marketing", Journal of Marketing, Vol. 58, No. 3, pp. 20-38.

Pels, J., Coviello, N., and Brodie, R. (2000), "Integrating transactional and relational marketing exchange: a pluralistic perspective", Journal of Marketing Theory and Practice, Vol. 8, No. 3, pp. 11-20.

Perry, C. (1998), "Processes of a case study methodology for postgraduate research in marketing", European Journal of Marketing, Vol. 32, No. 9/10, pp. 785-802.

Perry, M. K. (1989), "Vertical integration: determinants and effects", in Schmalensee, R. and Willig, R. D. (Eds.), Handbook of Industrial Organisation. Amsterdam: Elsevier, pp. 103-255. 
Pettigrew, A. M., Woodman, R. W., and Cameron, K. S. (2001), "Studying organizational change and development: challenges for future research", Academy of Management Journal, Vol. 44, No. 4, pp. 697-713.

Price, L. L. and Arnould, E. J. (1998), "Commercial friendships: service provider - client relationships in context", Journal of Marketing, Vol. 63, No. 4, pp. 38-56.

PVE (2003) IKB \& Kwaliteit, IKB varkens, www.veevleesei.nl.

Ratzan, S. C. (1998), The Mad Cow Crisis. London: UCL Press.

Saxowsky, D. M. and Duncan, M. R. (1998), Understanding Agriculture's Transition into the 21 st Century - Challenges, Opportunities, Consequences and Alternatives, Report No. 181. North Dakota State University, Fargo, North Dakota: Department of Agricultural Economics.

Selnes, F. (1998), "Antecedents and consequences of trust and satisfaction in buyer-seller relationships", European Journal of Marketing, Vol. 32, No.3/4, pp. 305-322.

Seth, A. and Randall, G. (2001), The Grocers, 2nd ed. London: Kogan Page.

Sharp, J. C. M. and Reilly, W. J. (1994), "Recent trends in foodborn infections in Europe and North America", British Food Journal, Vol. 96, No. 7, pp. 25-34.

Sporleder, T. L. (1992), "Managerial economics of vertically coordinated agricultural firms", American Journal of Agricultural Economics, Vol. 74, No. 5, pp. 1226-1231.

Srivastava, R. (1999), Transaction in the International Pork Industry. Policy Branch, Ottawa, Ontario: Economic and Policy Analysis Division.

Srivastava, R., Ziggers, G. W., and Schrader, L. (1998), "Vertical coordination in the swine industry: a multi-country study", in Ziggers, G. W., Trienekens, J. H., and Zuurbier, P. J. P. (Eds.), Proceedings of the 3rd International Conference on Chain Management in Agribusiness and the Food Industry, Wageningen Agricultural University, Ede, pp. 269-280. 
Steenkamp, Jan-Benedict E. M. (1997) "Dynamics in Consumer Behaviour with Respect to Agricultural and Food Products," in Berend Wieringa, Aad van Tilburg, Klaus Grunert, JanBenedict E. M. Steenkamp and Michel Wedel (Eds), Agricultural Marketing and Consumer Behaviour in a Changing World. Dordrecht: Kluwer Academic Publishers, pp.143-188.

ten Hooven, M. (2003) "Handel in vlees wordt vaak omzeild," Boerderij/Varkenshouderij, Vol. 88, No. 13, pp. 14-16.

Topigs (2003), Organisatie, www.topigs.nl.

Urlings, H. A. P., Walstra, P., and Tacken, G. M. L. (2000), Marktgericht werken in de varkensvleesketen. Presentation at Veehouderijsystemen van de toekomst, 20 April, Utrecht, WwW.vsys.nl.

Verbeke, W. (2001), "Beliefs, attitude and behaviour towards fresh meat revisited after the Belgian dioxin crises", Food Quality and Preference, Vol. 12, No. 8, pp. 489-498.

Verbeke, W. and Viaene, J. (1999), "Beliefs, attitude and behaviour towards fresh meat consumption in Belgium: empirical evidence from a consumer survey", Food Quality and Preference, Vol. 10, No. 6, pp. 437-445.

Verdonk, J. (2001), Toekomst in de agro-foodsector: Over ontwikkelingen in de agrarische-en voedingsmiddelensector. Den Haag: Ministerie van Landbouw, Natuurbeheer en Visserij.

Visser, J. J., Vlaar, P. W. L., and Neves, M. F. (2000), "The concept of power illustrated with the Dutch pork chain", in Trienekens, J. H. and Zuurbier, P. J. P. (Eds.), Proceedings of the 4th International Conference on Chain Management in Agribusiness and the Food Industry, 25-26 May. Ede: Wageningen Agricultural University \& The Foundation for Agri-Chain Competence, pp. 379-387.

Wandel, M. (1994), "Understanding consumer concern about food-related health risks", British Food Journal, Vol. 96, No. 7, pp. 35-40. 
www.abnamro.nl/download/agrarisch/varkenshouderij.pdf.

Yin, R. K. (1994), Case Study Research, 2nd ed.. Thousand Oaks, California: Sage Publications.

Ziggers, G. W. (1998), A Multi-country Study of Vertical Coordination in the Hog/Pork Industry.

Ede: Department of Management Studies, Wageningen Agricultural University. 
Table 1a. Types of marketing classified by relational exchange dimensions

\begin{tabular}{|c|c|c|c|c|c|}
\hline \multirow[t]{2}{*}{$\begin{array}{l}\text { Exchange } \\
\text { dimension }\end{array}$} & \multirow{2}{*}{\begin{tabular}{l}
\multicolumn{1}{c}{$\begin{array}{c}\text { Transactional } \\
\text { perspective }\end{array}$} \\
$\begin{array}{l}\text { Type: transaction } \\
\text { marketing }\end{array}$
\end{tabular}} & \multicolumn{4}{|c|}{$\begin{array}{c}\text { Relational } \\
\text { perspective }\end{array}$} \\
\hline & & $\begin{array}{l}\text { Type: database } \\
\text { marketing }\end{array}$ & Type: e-marketing & $\begin{array}{l}\text { Type: interaction } \\
\text { marketing }\end{array}$ & $\begin{array}{l}\text { Type: network } \\
\text { marketing }\end{array}$ \\
\hline Purpose of exchange & Economic transaction & $\begin{array}{l}\text { Information and } \\
\text { economic transaction }\end{array}$ & $\begin{array}{l}\text { Information-generating } \\
\text { dialogue between a } \\
\text { seller and many } \\
\text { identified buyers }\end{array}$ & $\begin{array}{l}\text { Interpersonal } \\
\text { relationships between a } \\
\text { buyer and seller }\end{array}$ & $\begin{array}{l}\text { Connected relationships } \\
\text { between firms }\end{array}$ \\
\hline Nature of communication & Firm 'to' mass market & $\begin{array}{l}\text { Firm 'to' targeted } \\
\text { segment or individuals }\end{array}$ & $\begin{array}{l}\text { Firm using technology } \\
\text { to communicate 'with' } \\
\text { and 'among' many } \\
\text { individuals (who may } \\
\text { form groups) }\end{array}$ & $\begin{array}{l}\text { Individuals 'with' } \\
\text { individuals (across } \\
\text { organizations) }\end{array}$ & $\begin{array}{l}\text { Firms 'with' firms } \\
\text { (involving individuals) }\end{array}$ \\
\hline Type of contact & $\begin{array}{l}\text { Arms-length, } \\
\text { impersonal }\end{array}$ & $\begin{array}{l}\text { Personalized (yet } \\
\text { distant) }\end{array}$ & $\begin{array}{l}\text { Interactive (via } \\
\text { technology) }\end{array}$ & $\begin{array}{l}\text { Face-to-face, } \\
\text { interpersonal (close, } \\
\text { based on commitment, } \\
\text { trust, and co-operation) }\end{array}$ & $\begin{array}{l}\text { Impersonal - } \\
\text { interpersonal (ranging } \\
\text { from distant to close) }\end{array}$ \\
\hline Duration of exchange & $\begin{array}{l}\text { Discrete (yet perhaps } \\
\text { over time) }\end{array}$ & Discrete and over time & $\begin{array}{l}\text { Continuous (but } \\
\text { interactivity occurs in } \\
\text { real time) }\end{array}$ & $\begin{array}{l}\text { Continuous (ongoing } \\
\text { and mutually adaptive, } \\
\text { may be short or long } \\
\text { term) }\end{array}$ & $\begin{array}{l}\text { Continuous (stable yet } \\
\text { dynamic, may be short } \\
\text { or long term) }\end{array}$ \\
\hline Formality in exchange & Formal & $\begin{array}{l}\text { Formal (yet } \\
\text { personalized via } \\
\text { technology) }\end{array}$ & $\begin{array}{l}\text { Formal (yet customized } \\
\text { and/or personalized via } \\
\text { interactive technology) }\end{array}$ & $\begin{array}{l}\text { Formal and informal } \\
\text { (i.e., both a business } \\
\text { and social level) }\end{array}$ & $\begin{array}{l}\text { Formal and informal } \\
\text { (i.e., both a business } \\
\text { and social level) }\end{array}$ \\
\hline
\end{tabular}

Source: Coviello, Milley, and Marcolin (2001: p. 28) 
Table 1b. Types of marketing classified by managerial dimensions

\begin{tabular}{|c|c|c|c|c|c|}
\hline \multirow[t]{2}{*}{$\begin{array}{l}\text { Managerial } \\
\text { dimension }\end{array}$} & \multirow{2}{*}{\begin{tabular}{l}
\multicolumn{1}{c}{$\begin{array}{c}\text { Transactional } \\
\text { perspective }\end{array}$} \\
$\begin{array}{l}\text { Type: transaction } \\
\text { marketing }\end{array}$
\end{tabular}} & \multicolumn{4}{|c|}{$\begin{array}{l}\text { Relational } \\
\text { perspective }\end{array}$} \\
\hline & & $\begin{array}{l}\text { Type: database } \\
\text { marketing }\end{array}$ & Type: E-marketing & $\begin{array}{l}\text { Type: interaction } \\
\text { marketing }\end{array}$ & $\begin{array}{l}\text { Type: network } \\
\text { marketing }\end{array}$ \\
\hline Managerial intent & $\begin{array}{l}\text { Customer attraction (to } \\
\text { satisfy the customer at a } \\
\text { profit) }\end{array}$ & $\begin{array}{l}\text { Customer retention (to } \\
\text { satisfy the customer, } \\
\text { increase profit, and } \\
\text { attain other objectives, } \\
\text { such as increased } \\
\text { loyalty, decreased } \\
\text { customer risk, etc.) }\end{array}$ & $\begin{array}{l}\text { Creation of IT-enabled } \\
\text { dialogue }\end{array}$ & $\begin{array}{l}\text { Interaction (to } \\
\text { establish, develop, and } \\
\text { facilitate a co-operative } \\
\text { relationship for mutual } \\
\text { benefit) }\end{array}$ & $\begin{array}{l}\text { Coordination } \\
\text { (interaction between } \\
\text { sellers, buyers, and } \\
\text { other parties across } \\
\text { multiple firms for } \\
\text { mutual benefit, } \\
\text { resource exchange, } \\
\text { market access, etc.) }\end{array}$ \\
\hline Managerial focus & Product or brand & $\begin{array}{l}\text { Product/brand and } \\
\text { customers (in a } \\
\text { targeted market) }\end{array}$ & $\begin{array}{l}\text { Managing IT-enabled } \\
\text { relationships between the } \\
\text { firm and many } \\
\text { individuals }\end{array}$ & $\begin{array}{l}\text { Relationships between } \\
\text { individuals }\end{array}$ & $\begin{array}{l}\text { Connected } \\
\text { relationships between } \\
\text { firms (in a network) }\end{array}$ \\
\hline Managerial investment & $\begin{array}{l}\text { Internal marketing } \\
\text { assets (focusing on } \\
\text { product/service, price, } \\
\text { distribution, promotion } \\
\text { capabilities) }\end{array}$ & $\begin{array}{l}\text { Internal marketing } \\
\text { assets (emphasizing } \\
\text { communication, } \\
\text { information, and } \\
\text { database technology } \\
\text { capabilities) }\end{array}$ & $\begin{array}{l}\text { Internal operational } \\
\text { assets (IT, website, } \\
\text { logistics); functional } \\
\text { systems integration }\end{array}$ & $\begin{array}{l}\text { External market assets } \\
\text { (focusing on } \\
\text { establishing and } \\
\text { developing a } \\
\text { relationship with } \\
\text { another individual) }\end{array}$ & $\begin{array}{l}\text { External market assets } \\
\text { (focusing on } \\
\text { developing the firms } \\
\text { position in a network of } \\
\text { firms) }\end{array}$ \\
\hline Managerial level & $\begin{array}{l}\text { Functional marketers } \\
\text { (e.g., sales manager, } \\
\text { product manager) }\end{array}$ & $\begin{array}{l}\text { Specialist marketers } \\
\text { (e.g., customer service } \\
\text { manager, loyalty } \\
\text { manager) }\end{array}$ & $\begin{array}{l}\text { Marketing specialists } \\
\text { (with) technology } \\
\text { specialists; senior } \\
\text { managers }\end{array}$ & $\begin{array}{l}\text { Employees and } \\
\text { managers from across } \\
\text { functions and levels in } \\
\text { the firm }\end{array}$ & Senior manager \\
\hline
\end{tabular}

Source: Coviello, Milley, and Marcolin (2001: p. 28) 
Table 2. Dutch pork supply chain: generic and study-specific description

\begin{tabular}{|c|c|c|}
\hline & $\begin{array}{l}\text { Supply chain } \\
\text { component }\end{array}$ & $\begin{array}{l}\text { Case study } \\
\text { details }\end{array}$ \\
\hline$\frac{2}{\underbrace{2}_{0}}$ & $\begin{array}{l}\text { The small number of large suppliers (Cehave, Hendrix UTD, and De Heus } \\
\text { Brokking Koudijs) is capital intensive and relies on economies of scale } \\
\text { (Visser, Vlaar, and Neves, 2000). Most suppliers produce according to the } \\
\text { 'Good Manufacturing Practice (GMP)' code, and pork producers who follow } \\
\text { the IKB scheme are required to buy their feed products from GMP suppliers } \\
\text { (Anonymous, 1999; PVE, 2003). }\end{array}$ & $\begin{array}{l}\text { The feed supplier chosen for the case is one of the biggest private feed producer } \\
\text { in the Netherlands. Although it belongs to the same holding as the case } \\
\text { slaughterhouse/meat processor (an international company with a leading } \\
\text { position in high-quality foods for human and animal consumption) they are } \\
\text { separate companies. }\end{array}$ \\
\hline$\frac{\mathscr{2}}{\frac{0}{\mathscr{d}}}$ & $\begin{array}{l}\text { Dealers or merchants are a common component of the supply chain offering } \\
\text { local service, stockholding, a range of products and services and credit/cash } \\
\text { collection. }\end{array}$ & $\begin{array}{l}\text { The case feed supplier employs a dealer system according to which dealers sell } \\
\text { feed from the feed company to pig producers. Dealers also supply technical } \\
\text { products such as fertilizers, biological feed etc. The majority of the feed supplier } \\
\text { dealers are small companies; one of these was chosen. }\end{array}$ \\
\hline 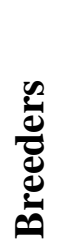 & $\begin{array}{l}\text { With a } 60 \text { percent market share, Topigs is the dominating player (Topigs, } \\
2003 \text { ). Most of the breeders focus on fertility, which determines the number } \\
\text { of pigs born to each sow for subsequent fattening, and production features, } \\
\text { such as the ability to efficiently convert feed into lean meat. These features } \\
\text { are highly valued by producers (Ziggers, 1998) }\end{array}$ & \\
\hline
\end{tabular}


Table 2. Dutch pork supply chain: generic and study-specific description, continued

\begin{tabular}{|c|c|c|}
\hline & $\begin{array}{c}\text { Supply chain } \\
\text { component }\end{array}$ & $\begin{array}{c}\text { Case study } \\
\text { details }\end{array}$ \\
\hline 赵 & $\begin{array}{l}\text { Due to a decrease in the number of producers on the one hand and an increase } \\
\text { in the number of farrow-to-finish pig farms, that grow pigs from birth to } \\
\text { slaughter weight, the number of traders have decreased steadily (Ziggers, } \\
\text { 1998). The task of a trader is now to bring supply and demand together and to } \\
\text { facilitate information exchange between producers and slaughterhouses, } \\
\text { which means that confidentiality among the three members is of importance } \\
\text { (Visser, Vlaar, and Neves, 2000). The slaughterhouses believe that it is } \\
\text { cheaper to use traders than to set up their own buyer network (Maijers et al., } \\
\text { 1999; Ziggers, 1998). }\end{array}$ & $\begin{array}{l}\text { There are about } 40 \text { traders in the trader network of the slaughterhouse (meat } \\
\text { processor) chosen for this study, who also deliver to other slaughterhouses. The } \\
\text { trader, who participated in the research has } 58 \text { different suppliers and delivers to } \\
\text { the case slaughterhouse and one other slaughterhouse. }\end{array}$ \\
\hline 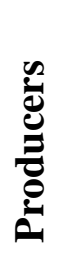 & $\begin{array}{l}\text { The number of pigs processed in the Netherlands has decreased from more } \\
\text { than } 14 \text { million in } 1996 \text { a year to } 11 \text { million a year in } 2002 \text {. At the same time, } \\
\text { the number of pig farms has decreased, whilst the average number of pigs has } \\
\text { increased to } 983 \text { pigs/farm in } 2002 \text { (CBS, 2002; PVE, 2002). Most producers } \\
\text { are family-owned businesses. The pork supply structure in the Netherlands is } \\
\text { strongly fragmented and there is little cooperation among producers. }\end{array}$ & $\begin{array}{l}\text { Some } 1,500 \text { producers deliver to the case slaughterhouse, } 85 \text { percent using } \\
\text { traders and } 15 \text { percent directly (Burgers, 2003). Most pig-producing farms are } \\
\text { family owned (Ziggers, 1998). Three medium-sized companies - with an annual } \\
\text { production of } 1,100-1,600 \text { slaughtered pigs delivered by traders to the } \\
\text { slaughterhouse - participated in the research. }\end{array}$ \\
\hline 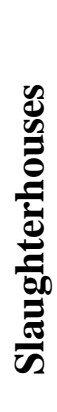 & $\begin{array}{l}\text { Take-overs and the formation of alliances have reduced the number of } \\
\text { slaughterhouses to seven in } 2003 \text { (NMa, 2001; ten Hooven, 2003). With a } \\
\text { market share of } 50 \text { percent and an annual production of } 7.5 \text { million pigs, } \\
\text { Dumeco is the biggest slaughterhouse in the Netherlands; the Hendrix Meat } \\
\text { Group (HMG) is second with an annual production of } 2.3 \text { million pigs (ABN } \\
\text { AMRO, 2002). }\end{array}$ & $\begin{array}{l}\text { The case slaughterhouse is one of the biggest in the Netherlands. It slaughters } \\
\text { and also process pigs. The pork meat is sold directly to meat processors ( } 40 \\
\text { percent), wholesalers ( } 15 \text { percent), and retailers ( } 40 \text { percent), or it is processed } \\
\text { by the slaughterhouse itself for the retailer which was chosen for this case. The } \\
\text { slaughterhouses' market segments are 'global pork' that is produced under the } \\
\text { IKB system and meets international standards; 'welfare pork' that meets } \\
\text { additional demands for animal welfare; 'greenline pork' that specifies that the } \\
\text { pigs have been antibiotic-free feed during a prescribed period of time; and } \\
\text { 'organic pork' where the pork has been produced according to particular organic } \\
\text { rules (Burgers, 2003). }\end{array}$ \\
\hline
\end{tabular}


Table 2. Dutch pork supply chain: generic and study-specific description, continued

\begin{tabular}{|c|c|c|}
\hline & $\begin{array}{l}\text { Supply chain } \\
\text { component }\end{array}$ & $\begin{array}{l}\text { Case study } \\
\text { details }\end{array}$ \\
\hline 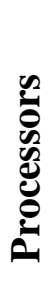 & $\begin{array}{l}\text { Characteristically, processing into for example joints is often integrated with } \\
\text { slaughtering operations. However, there are processors who purchase their } \\
\text { pork meat as whole carcasses. The } 33 \text { meat-processing firms identified in } \\
1997 \text { mostly exported their products. Meatpoint ( } 25 \text { percent), UVG ( } 20 \\
\text { percent), and Sara Lee ( } 10 \text { percent) are the biggest processors. Using } \\
\text { branding, some processors have succeeded in creating a strong market } \\
\text { position, e.g. Unox. }\end{array}$ & \\
\hline 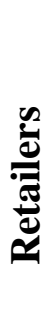 & $\begin{array}{l}\text { About } 80 \text { percent of all pork meat products in the Netherlands are sold } \\
\text { through retailers many of which have developed alliances in order to increase } \\
\text { their bargaining power. The market share of the four biggest retailers - Ahold, } \\
\text { Superuni, TSN, and Laurus - is } 89 \text { percent. With private labels becoming } \\
\text { more important retailers can increase their demands, especially regarding } \\
\text { safety, quality, consistency of supply, and reliability (Visser, Vlaar, and } \\
\text { Neves, 2000). }\end{array}$ & $\begin{array}{l}\text { The case company is one of the biggest Dutch retailers, with a market share of } \\
22 \text { percent. The retailer operates under different branches. Its most important } \\
\text { fresh meat supplier is the case-slaughterhouse. }\end{array}$ \\
\hline 窇 & $\begin{array}{l}\text { Over the years, consumer preferences have changed, and consumers are now } \\
\text { pressing for pork meat suppliers to consider environmental and welfare } \\
\text { issues. Consumers are also concerned with the quality of meat products, } \\
\text { nutritional value, sensory aspects, and ease of preparation. Products with an } \\
\text { image of being healthy are popular as are reasonably priced products } \\
\text { (Saxowsky and Duncan, 1998; Steenkamp, 1997; Verbeke, 2001; Verbeke } \\
\text { and Viaene, 1999). }\end{array}$ & \\
\hline
\end{tabular}


Table 3a. Changes in the pork supply chain

\begin{tabular}{|c|c|c|c|}
\hline Player & Findings & Player & Findings \\
\hline Feeder & $\begin{array}{l}\text { - Competition in the feeding sector is increasing due to } \\
\text { decreasing number of producers. } \\
\text { Consumers are increasingly asking for pork meat that has } \\
\text { been produced according to special guidelines; producers } \\
\text { are responding to these demands; and feeders must adjust } \\
\text { their market offerings. } \\
\text { Although IT (IT) is important the slaughterhouse (in the } \\
\text { case) is behind most IT initiatives. }\end{array}$ & Dealer & $\begin{array}{l}\text { - Suppliers must now approach their customers with } \\
\text { different offerings. } \\
\text { - Competition in the dealer sector is increasing due to } \\
\text { decreasing number of producers. } \\
\text { - New consumer demands present suppliers new market } \\
\text { opportunities for advising their customers on feed } \\
\text { materials. }\end{array}$ \\
\hline $\begin{array}{l}\text { Producers: three } \\
\text { medium-sized } \\
\text { producers }\end{array}$ & $\begin{array}{l}\text { Producers are facing mounting competition: pork meat } \\
\text { prices have dropped, labor costs are high, fixed costs have } \\
\text { increased, and rules regarding environmental issues are } \\
\text { becoming stricter. } \\
\text { - Food safety and animal welfare issues have attracted high } \\
\text { levels of public interest. } \\
\text { This means that producers have had to implement quality } \\
\text { systems and adjust management practice, which have } \\
\text { been time consuming and expensive. }\end{array}$ & Trader & $\begin{array}{l}\text { - Competition among the traders is increasing due to the } \\
\text { decreased number of producers. } \\
\text { Competition is also increasing because the number of } \\
\text { slaughterhouses (i.e. the customers) is decreasing due to } \\
\text { take-overs. } \\
\text { - IT is seen as threatening since it can offer many of the } \\
\text { services that traders are currently offering. } \\
\text { Traders have had to implement quality programs because } \\
\text { of consumers' concerns about food safety and animal } \\
\text { welfare. }\end{array}$ \\
\hline Slaughterhouse & $\begin{array}{l}\text { - Slaughterhouses are competing intensively because } \\
\text { producers are delivering fewer pigs, and the } \\
\text { slaughterhouses have increased their capacities. } \\
\text { - Slaughterhouses have had to face consumers' concern for } \\
\text { food safety and animal welfare, as well as governmental } \\
\text { restrictions. }\end{array}$ & Retailer & $\begin{array}{l}\text { An increased number of IT programs are being } \\
\text { implemented in order to deal with consumer demands on } \\
\text { food safety and animal welfare. }\end{array}$ \\
\hline
\end{tabular}


Table 3b. Changes in marketing practice

\begin{tabular}{|c|c|c|c|}
\hline Player & Findings & Player & Findings \\
\hline Feeder & $\begin{array}{l}\text { - Customer retention (not only retention of producers but } \\
\text { also slaughterhouses and retailers) becomes important } \\
\text { with increased competition. } \\
\text { - Feeders must be able to offer customized feed to } \\
\text { producers. }\end{array}$ & Dealer & $\begin{array}{l}\text { - The suppliers' customers are asking to be treated } \\
\text { individually, and the suppliers are approaching their } \\
\text { customers in a number of different ways. For example, in } \\
\text { order to answer producers' questions on environmental } \\
\text { issues the dealer is working together with an } \\
\text { environmental company. }\end{array}$ \\
\hline Slaughterhouse & $\begin{array}{l}\text { - Long-term relationships with the different players in the } \\
\text { pork chain are seen as important for keeping a cost- } \\
\text { efficient supply chain in place. } \\
\text { Relationships with producers and traders are key if } \\
\text { consumer demands are to be met. } \\
\text { The slaughterhouse has implemented IT changes as a } \\
\text { means for developing and retaining their relationships } \\
\text { with producers and traders. A Web site thus provides } \\
\text { information on slaughtered pigs (weights, fat quality, } \\
\text { deviations etc.). They have also implemented an } \\
\text { electronic quality system that ensures food safety }\end{array}$ & Retailer & $\begin{array}{l}\text { - Contact is often more direct with players upstream than } \\
\text { downstream. }\end{array}$ \\
\hline
\end{tabular}


Table 3c. Trust in the pork supply chain

\begin{tabular}{|c|c|c|c|}
\hline Player & Findings & Player & Findings \\
\hline Feeder & $\begin{array}{l}\text { - Retailers sometimes demand specific quality systems but } \\
\text { do not contribute toward the cost. } \\
\text { - Slaughterhouses unitarily decide which players get invited } \\
\text { to participate in particular quality systems. } \\
\text { If feeders are not participants in a quality system they do } \\
\text { not always receive enough information from the } \\
\text { slaughterhouses. } \\
\text { Feeders generally do not fully trust the slaughterhouses } \\
\text { and retailers. }\end{array}$ & Dealer & $\begin{array}{l}\text { The suppliers do not get enough information from the } \\
\text { retailers with regard to the finish food products and the } \\
\text { consumers' preferences to advice on how feed can change } \\
\text { different quality aspects of meat. } \\
\text { - The dealer trusts the different players in the pork supply } \\
\text { chain although they believe that there is a lack of trust } \\
\text { between producers and slaughterhouses. }\end{array}$ \\
\hline $\begin{array}{l}\text { Producers: three } \\
\text { medium-sized } \\
\text { producers }\end{array}$ & $\begin{array}{l}\text { Producers believe that they do not receive all information } \\
\text { slaughterhouses and retailers on price settings, and they } \\
\text { feel that the slaughterhouses and retailers abuse their } \\
\text { power in order to make extra profit. } \\
\text { Trust toward the slaughterhouses and retailers is generally } \\
\text { low. One case in point is when slaughterhouses say that } \\
\text { they accept to pay more for meat of certain qualities, but } \\
\text { then refuse to do so. }\end{array}$ & Trader & $\begin{array}{l}\text { - Although there is little lack of information the } \\
\text { slaughterhouses could provide more information on the } \\
\text { pork market and prices. } \\
\text { It is felt that retailers are abusing their power by taking a } \\
\text { too high share of the chain profits, while slaughterhouses } \\
\text { import cheaper pork meat from foreign countries. } \\
\text { Traders also believe that slaughterhouses are } \\
\text { implementing IT changes as a means of dealing directly } \\
\text { with producers in the future. }\end{array}$ \\
\hline Slaughterhouse & $\begin{array}{l}\text { There is not a great lack of information that is missing, } \\
\text { and the reason why they do not always receive the } \\
\text { information they want is because the supply chain is not } \\
\text { fully integrated. } \\
\text { There is a lack of trust between the producers and } \\
\text { slaughterhouses. } \\
\text { The slaughterhouse is the connector between suppliers } \\
\text { (i.e. the producers) and customers (i.e. the retailers) and } \\
\text { has therefore been able to assume the role of chain leader. }\end{array}$ & Retailer & $\begin{array}{l}\text { - The power of slaughterhouses, it is felt, is too strong, and } \\
\text { there is little trust between the slaughterhouses and the } \\
\text { other players. }\end{array}$ \\
\hline
\end{tabular}


Table 4. Indexes by marketing type (bold = high levels)

\begin{tabular}{llllll}
\hline & $\begin{array}{l}\text { Transaction } \\
\text { marketing }\end{array}$ & $\begin{array}{l}\text { Database } \\
\text { marketing }\end{array}$ & E-marketing & $\begin{array}{l}\text { Interaction } \\
\text { marketing }\end{array}$ & $\begin{array}{l}\text { Network } \\
\text { marketing }\end{array}$ \\
\hline Feeder & 0.73 & 0.73 & 0.58 & $\mathbf{0 . 9 3}$ & $\mathbf{0 . 8 2}$ \\
Dealer & 0.64 & 0.71 & 0.62 & $\mathbf{0 . 9 6}$ & 0.73 \\
Pork-trader & 0.60 & 0.64 & 0.58 & $\mathbf{0 . 9 6}$ & 0.73 \\
Slaughterhouse & 0.60 & 0.62 & 0.58 & $\mathbf{0 . 9 1}$ & $\mathbf{0 . 8 4}$ \\
Retailer & $\mathbf{0 . 7 6}$ & $\mathbf{0 . 7 8}$ & $\mathbf{0 . 7 8}$ & 0.73 & 0.71 \\
Chain average & 0.67 & 0.70 & 0.63 & $\mathbf{0 . 9 0}$ & $\mathbf{0 . 7 7}$ \\
\hline
\end{tabular}

